\title{
Role of Petroleum Based Machines in Socio - Economic Development of Areca Nut Growers -A Sociological Study (With special reference to Chikkamagalore District)
}

\section{R.Devananda}

Research Scholar

Bharathiar University,

Coimbatore, Tamilnadu

Email:devanandar59@gmail.com
Dr. G. D Narayana

Research Supervisor

Dept. of PG studies and Research Sociology,

Bharathiar University,

Coimbatore, Tamilnadu
Abstract

The word petroleum comes from Greek. The term frequently used to refer to mineral oils produced by distillation from mined organic solids such as cannel coal and refined oils produced from them, they are derived from crude oil as it is processed in oil refineries, they are collection of well defined pure chemical compounds, petroleum products are complex mixtures.

Petroleum products are very essential products for transportation, heating, electricity generation, asphalt and road oil. They are used to make chemicals, plastics and synthetic materials which we are using in daily life. About $74 \%$ of the 6.89 billion barrels of petroleum that we used in 2013 were gasoline, heating oil/diesel fuel and jet fuel.
Reference to this paper should be made as follows:

R. Devananda, Dr. G. D Narayana

Role of Petroleum Based Machines in Socio - Economic

Development of Areca Nut Growers - A

Sociological Study

Journal Global Values, Vol. XI, No.I, Article No.13

pp. 101-113

http://anubooks.com/

?page_id $=6195$

https://doi.org/

10.31995/

jgv.2020.v11i01.013 
Role of petroleum Based Machines in Socio - Economic Development of Areca nut growers -A Sociological study

R.Devananda, Dr. G. D Narayana

\section{Intrduction}

\section{Petrol Stations in India}

According to 20 January 2015 there are 51,870 petrol pumps are working India. According to 20 January 2015 there are 2500 petrol pumps working in Karnataka state. Those obtained from crude oil and natural gas processing, including (among many others) asphalts, automotive gasoline's, aviation gasoline's, fuel oils, kerosene, liquefied petroleum gas (LPG), lubricants, naphtha's, and waxes.

India is the second most populous country in the world, with over 1.277 billion people (2015), more than a sixth of the world's population. Already containing $17.5 \%$ of the world's population, India is projected to be the World's by 2022, surpassing China, its population reaching 1.6 billion by 2050 . Its population growth rate is $1.2 \%$, ranking 94th in the world in 2013 . The Indian population had reached the billion marks by 1998 .

India has more than $50 \%$ of its population below the age of 25 and more than $65 \%$ below the age of 35 . It is expected that, in 2020 , the average age of an Indian will be 29 years, compared to 37 for China and 48 for Japan; and, by 2030, India's dependency ratio should be just over 0.4.

\section{Petroleum Based Machines}

Petroleum based machines are those machines which works through petroleum product like petrol, Diesel and lubricants.In now a day's agriculturist's mainly Aracanut growers in our chikkamagalore district are using machinery in all stages from beginning to prepare the land to plant Aracanut saplings to manufacture of Aracanut powder for human consumption in the last end.

Aracanut farmers are using bulldozers, JCB's, tractors, power tillers, water lifting pump's, generators, commercial vehicles , trucks, drying machines, mixing machines, Raw Aracanut De-huskers machines, Dry chaly De-huskers machines, Aracanut crushing machines, jeeps, cars, motor bikes and other machines for the Aracanut cultivation generally .Aracanut growers are using above said petroleum based machines because of lack of laborers, lack of bulks, lack of bulk carts to till the land and to transport the Aracanut products and other required materials for their use.

\section{Aracanut}

In Karnataka state Aracanut is a main commercial crop in practice. It was earlier grown in malanadu regions, coastal regions, and side of sahyadri mountain regions. But in now a day'sAracanut is growing in table lands (BayaluSeemae) also. For Aracanut crop sandy soil, red soil, jambbeittige soil, meccalusoil is suitable. 
Aracanut crop needs more rain and water whenever is needed. It is sustainable to hot climate also. The life time of Aracanut tree is about 50 to 60 years. From the time of Mahabharata, Ramayana and till today Aracanut is growing and utilizing by the human kind in India. There are evidences for the Aracanut crop in the past history.

The obstacles posed by Aracanut are numerous. Aracanut has given more obstacles then happiness to the Aracanut growers in past, present and in future also. Aracanut is a traditional and holy crop which as more importance in the life of human beings. Aracanut is a essential for human beings in Hindu religion from birth day to death day. Aracanut has got medicinal values and nutri-ceutical properties which will help the human health as stated in Ayurveda history.

The Aracanut is found to be useful for major ailments as under Leucoderma, leprosy, gonorrhea, urinary problems, scabies, cough, fits, stomach worms, anemia, obesity, as a stimulant, appetizer, expelling gas and phlegm, strengthening the gums, teeth and cleans, deodorizes mouth and bad odor, dysentery, diarrhea, heart burn, urinary stones, in controlling diabetes, excessive passing of flatulent, colic, hyper acidity, gastric ulcer, nasal ulcers , nasal ulcers promotion of menstrual flow, to check the pyrosis of pregnancy in women, improvement of memory in Alzheimer patients. The details are given in report of the department of agricultural economics (2012).

Aracanut leaves are using in manufacturing of bio-degradable plates, bolus, cup's and others for diner purpose. Aracanut leaves are using to manufacture Food stocks for cows and other animals which helps in milk industry. Aracanut facing a cut-thought lobby from tobacco industry, liquor industry, gutka industry and multinational companies also in recent days.

Aracanut crop is like a 'Maya jinke' for Aracanut growers. It influences marginal farmers, small farmers and big land lords also. Some times Aracanut crop deceives all the growers and the marketing people from top to Bottom, in financial concerns. Even then Aracanut growers are hoping on Aracanut crop for their lively hood.

The main problems are Aracanut growers are conservation of crop and market only. For the cultivation of Aracanut the cost of cultivation is varies from place to place but in the eyes of Aracanut market all Aracanut growers are equal. Has said in Sanskrit "Anyatham-Sharanam-Nasti!".

There are different types of Aracanut verities appi, rashiedi, kempaedi, gorabalu, saraku, halavu, chaly, and others. At present total Aracanut productions in India is 7 lakhstons. In recent days due to the unhealthy love on money and income, 
Role of petroleum Based Machines in Socio - Economic Development of Areca nut growers -A Sociological study

R.Devananda, Dr. G. D Narayana

some growers, commission agents, traders, Aracanut powder manufactures and unknown middle men's destroyed the social, relational reputation of Aracanut. So it went to the apex court of India (Supreme Court of India). A legal battle is going on Aracanut crop in the apex court of India. So many writ pet ions and public interest litigations are pending before several high courts of India also.

Afterthe LPG (liberalization,Privatizationand Globalization) which started in India in the year 1991 has brought some serious effects on Aracanut crop and growers in the name of import and export policy of India. That too especially with SAARC countries, the member states are Afghanistan, Bangladesh, Bhutan, India, Maldives, Nepal, Pakistan, and Sri Lanka. SAARC was founded by seven states in 1985.

From the above SAARC counties Aracanut is importing legally and illegally. This affects the entire market and standard of Aracanut finally the Aracanut growers also. Corers of people are depending directly and indirectly for their livelihood. By the intervention of cooperative movement in Aracanut crop has changed the face value of Aracanut growers in large, co operative societies like MAMCOS,CAMPCO, TSS SIRSI, TUMCOS,DAMCOS and other Aracanut growers and marketing societies are working for the welfare of Aracanut growers are large.

\section{Objectives of the research article}

v To study the contributions of petroleum Based Machines in Aracanut farming.

$\mathrm{v}$ To analyze the economic development of Aracanut growers.

v To study about the social conditions of Aracanut growers.

\section{Hypothesis of the research article}

$\mathrm{v}$ At present Aracanut growers economical condition is normal.

v Nontraditional Aracanut grower's social condition is good.

$\mathrm{v}$ Without the help of petroleum based machines Aracanut cultivation is very difficult.

\section{Statement clarification}

\section{Petroleum Based Machines}

Petroleum based machines are those machines which works through petroleum product like petrol, Diesel and lubricants like bulldozers, JCB's, tractors, power tillers, water lifting pump's, generators, commercial vehicles , trucks, drying machines, mixing machines, Raw Aracanut De-huskers machines, Dry chaly Dehuskers machines, Aracanut crushing machines, jeeps, cars, motor bikes and other machines for the Aracanut cultivation. 


\section{Socio -Economic development}

Here we considered social and economical developmental aspects of life areca nut growers.

\section{Areca nut growers}

Areca nut growers are nothing but like other crofts growers. But here we considered Areca nut growers are growing area nut in plantation style.

\section{Sociological study}

It is the systematic and scientific study method of social issues with historical, religious, educational, economical, and political, Social and other perspectives

\section{Methodology}

In this study we have used simple random sampling method on selected on 50 respondents. We have used direct interview method for the collection of information by the respondents. Who are using petroleum based machines for Aracanut cultivation. We used primary and secondary sources to collect the data with structural development perspective.

\section{Sources of information}

1) Primary resources: - To collect the primary information I used self prepared questionnaire on development perspective for interview. Finally information is collected by 50 respondents.

2) Secondary sources: - We have collected information Articles, journals, library, newspapers and websites.

\section{Theoretical Perspective}

We used structural functional theoretical perspective for this success of study.

\section{Topographical features of the study}

Chikkamagalore is a district in the South Indian state of Karnataka. Coffee was first cultivated in India in Chikkamagalore. The mountains in Chikkamagalore which are a part of the Western Ghats are the source of rivers like Tunga and Bhadra. Geographical scope of study area is chikkamagalore dist., in Karnataka state regarding public policy and sustainable development. Chikkamagalore dist., will come under the famous western guts' area, Chikkamagaloredist famous for Coffee, tea, Cardamom, Rubber plantation crops. It is also famous for horticulture corps like coconut, Aracanut, Banana, Mango, Sapota and other crops. It is also famous for Paddy, Raghi, Jower and other food crops. It is also famous for commercial crops like chilies, Oninen, Potato and other crops. It is also famous for tourism sports 
Role of petroleum Based Machines in Socio - Economic Development of Areca nut growers -A Sociological study

R.Devananda, Dr. G. D Narayana

like Dattapita, Mullaiyanagiri, Kallatthigiri, Kemmannagundi, Amruthapura temple and so on. Information regarding chikkamagalore dist., as on today. There are BPC - 18, HPC-24, IOC-30, Reliance-02, SR-01 total 75 bunks.

\section{According to 2011 census}

Geographical location12 54' and 13 53' north latitude, 75 04' and 7621' East longitude, Temperature is 310C (Max), 140C (Min),AverageRainfall is $1925 \mathrm{~mm}$. Rivers are Tunga, Bhadra, Vedavathi, Yagachi, Hemavati and Netravathi. Area is $7201 \mathrm{sq} \mathrm{km}$. District headquarter is Chikkamagalore. Population are 10,17,283. Density of Population is $158 / \mathrm{km}$. Sex ratio is Female 969 per 1000 male. Literacy rate is $79.25 \%$ (Male $85.41 \%$ and Female $73.16 \%$ ). Major Industrial areas are Chikkamagalore -13.45 acres, Birur - 11.25 acres ,N. R. Pura - 10.00 acres ,Amble Industrial,- 144.23 acres.

As on 2013-2014 Horticulture detail statics of Govt. of Karnatakastate

\begin{tabular}{|l|l|l|l|l|}
\hline SI.No. & Name of The Taluk & $\begin{array}{l}\text { Areain } \\
\text { Hectares }\end{array}$ & $\begin{array}{l}\text { Crops } \\
\text { In Tones }\end{array}$ & $\begin{array}{l}\text { Yield/Hectares In } \\
\text { Tones }\end{array}$ \\
\hline 01 & Chikkamagalore & 1295 & 1295 & 1 tons/ hectares \\
\hline 02 & Kadur & 14000 & 19,880 & 1.42 tons/ hectares \\
\hline 03 & Tarikere & 9,432 & 18,864 & 2.0 tons/ hectares \\
\hline 04 & Mudigere & 2,599 & 2,780 & 1.07 tons/ hectares \\
\hline 05 & Koppa & 4,800 & 4,128 & 0.86 tons/ hectares \\
\hline 06 & Sringeri & 2,490 & 1,624 & 0.65 tons/ hectares \\
\hline 07 & N.R.Pura & 2,364 & 494 & 0.19 tons/ hectares \\
\hline \multicolumn{2}{r}{ Total } & 36,980 & 49,015 & 1.33 tons/ hectares \\
\hline
\end{tabular}

\section{Karnataka state}

\begin{tabular}{|l|l|l|l|}
\hline 175 Taluks & $2,51,185$ hectares & $3,67,303$ tons & 1.46 tons/ hectares \\
\hline
\end{tabular}

\section{Data Analysis}

The data collected by using all the research methods, and others sources are analyzed by essential statistical techniques by using analysis of data research report. The data was collected on structural development perspective.

Table. 1 Personal Profile of The Respondens

\begin{tabular}{|c|c|c|c|c|c|}
\hline SL & \multicolumn{5}{|c|}{ Personal profile of the Respondents } \\
\hline \multirow{2}{*}{1} & \multirow{2}{*}{ Age } & $18-28$ & 29-39 & $40-50$ & $51+$ \\
\hline & & 18 & 20 & 04 & 08 \\
\hline \multirow{2}{*}{2} & \multirow{2}{*}{ Gender } & \multicolumn{3}{|c|}{ Male } & Female \\
\hline & & \multicolumn{3}{|c|}{40} & 10 \\
\hline
\end{tabular}




\begin{tabular}{|c|c|c|c|c|c|c|}
\hline \multirow{2}{*}{3} & \multirow{2}{*}{ Caste } & $\mathrm{SC}$ & ST & $\mathrm{OBC}$ & \multicolumn{2}{|c|}{ Others } \\
\hline & & 10 & 08 & 15 & \multicolumn{2}{|c|}{05} \\
\hline \multirow{2}{*}{4} & \multirow{2}{*}{ Religion } & Hindu & \multicolumn{2}{|c|}{ Christian } & \multicolumn{2}{|c|}{ Muslim } \\
\hline & & 38 & \multicolumn{2}{|c|}{05} & \multicolumn{2}{|c|}{07} \\
\hline \multirow[t]{2}{*}{5} & \multirow{2}{*}{ Education } & Illiterates & $\begin{array}{c}\text { Primary } \\
\text { education }\end{array}$ & $\begin{array}{l}\text { Secondary } \\
\text { education }\end{array}$ & \multicolumn{2}{|c|}{$\begin{array}{c}\text { Higher } \\
\text { education }\end{array}$} \\
\hline & & 00 & 24 & 20 & \multicolumn{2}{|c|}{6} \\
\hline \multirow[t]{2}{*}{6} & \multirow{2}{*}{$\begin{array}{l}\text { Yearly } \\
\text { Income }\end{array}$} & $\begin{array}{c}\text { Up to } \\
25,000 \\
\end{array}$ & $\begin{array}{c}25,001 \text { to } \\
50,000\end{array}$ & $\begin{array}{l}50,001 \text { to } \\
1,00,000 \\
\end{array}$ & \multicolumn{2}{|c|}{$\begin{array}{c}1,00,001+a b o v \\
\mathrm{e}\end{array}$} \\
\hline & & 20 & 21 & 6 & \multicolumn{2}{|c|}{3} \\
\hline \multirow{2}{*}{7} & \multirow{2}{*}{ Marriage } & Married & Bachelor & Widow & & \\
\hline & & 25 & 20 & 5 & & \\
\hline \multirow{2}{*}{8} & \multirow{2}{*}{ Family } & Joint & Nuclear & & & \\
\hline & & 02 & 48 & & & \\
\hline \multirow[t]{2}{*}{9} & \multirow{2}{*}{$\begin{array}{c}\text { Areca nut } \\
\text { plants in } \\
\text { acres }\end{array}$} & $0-5$ & $06-10$ & $11-15$ & $16-20$ & $\begin{array}{c}20 \\
+ \\
\end{array}$ \\
\hline & & 10 & 10 & 20 & 10 & 10 \\
\hline
\end{tabular}

In demographic information age, gender, education qualification, , marital status, income size type of family etc, are various information's are followings

- Age: Age is the important factor at the time of interviewee because if the respondents are below 18 years age there will be considered as minors. They are not eligible into any contract according to Indian contract act1872.

- Gender:We interviewed $80 \%$ of the male respondents. $20 \%$ of the female respondents.

- Cast: At the time of research in India cast plays a important role even though India is secular state. We interviewed $18 \% \mathrm{SC}, 17 \% \mathrm{ST}, 32 \% \mathrm{OBC}$ (08\% Veerashaivas, 7\% Vakkaligas, 8\% Kurubhas, 02\% Upparas, 01\% Devangas, $01 \%$ Maratees, $02 \%$ Banjaranaiks, $01 \%$ Gownders, $01 \%$ Achars, $01 \%$ Kuruvinshettys) and others $09 \%$.

- Religion: India is the mother land of several religions. Even though its. secular state all the statistics are collected on the basis of religion like Hindu, Muslim, Christian, Jains, Parasis, Buddhists, siks and so on.

o We interviewed Hindus 76\%, Christiyans 10\%, and Muslim 14\%.

Education:Education plays in important role in India. Due to several governmental and non-governmental (NGO's) intuitional efforts. Majority 
Role of petroleum Based Machines in Socio - Economic Development of Areca nut growers -A Sociological study

R.Devananda, Dr. G. D Narayana

of the respondents are literates. In the interview $48 \%$ as the primary education, $40 \%$ Secondary education and $12 \%$ higher education.

- Areca nut plants in acres: we are interviewed $20 \%$ areca nut growers are growing in 0 to 5 acres , 20\% areca nut growers are growing in 6to 10 acres, $30 \%$ areca nut growers are growing in 11 to 15 acres $20 \%$ areca nut growers are growing in 15 to 20 acres $20 \%$ areca nut growers are growing in5to 10 acres,

Table:2 Role of petroleum Based Machines usedby Arecanut growers

\begin{tabular}{|l|l|l|l|}
\hline $\begin{array}{l}\text { Sl. } \\
\text { No. }\end{array}$ & petroleum Based Machines & \multicolumn{1}{|c|}{ Yes } & No \\
\hline 01 & used bulldozers to level the land & $05 \%$ & $95 \%$ \\
\hline 02 & used JCB's to build the bunds & $10 \%$ & $90 \%$ \\
\hline 03 & tractors for cultivation for the areca nut plantation & $80 \%$ & $20 \%$ \\
\hline 04 & power tillers for areca nut cultivation & $60 \%$ & $40 \%$ \\
\hline 05 & water lifting machines for areca nut cultivation & $95 \%$ & $05 \%$ \\
\hline 06 & generators for areca nut cultivation to provide water for plants & $25 \%$ & $75 \%$ \\
\hline 07 & commercial vehicles for areca nut cultivation & $5 \%$ & $95 \%$ \\
\hline 08 & drying machines for areca nut processing & $25 \%$ & $75 \%$ \\
\hline 09 & Mixing machines for manufacturing areca nut powder & $2 \%$ & $98 \%$ \\
\hline 10 & Are you using Raw Areca nut De-husking machines & $50 \%$ & $50 \%$ \\
\hline 11 & Dry Areca nut De-husking machines & $10 \%$ & $90 \%$ \\
\hline 12 & crushing machines to manufacture areca nut powder & $5 \%$ & $95 \%$ \\
\hline 13 & jeeps to visit areca nut plantation & $5 \%$ & $95 \%$ \\
\hline 14 & Cars to visit areca nutplantation & $3 \%$ & $97 \%$ \\
\hline 15 & motor bikes to visit areca nutplantation & $90 \%$ & $10 \%$ \\
\hline 16 & income increased after using petroleum based machines & $90 \%$ & $10 \%$ \\
\hline 17 & social status is improved by using petroleum based machines & $95 \%$ & $5 \%$ \\
\hline
\end{tabular}

Table -3Socio Economic Development of Areca nut growersafter used the petroleum based machines

\begin{tabular}{|c|l|c|c|}
\hline S1 no & Aspects of Socio Econom ic Development of Areca nut growers & YES & No \\
\hline 1 & Improved of educational level & $60 \%$ & $40 \%$ \\
\hline 2 & Improved of Living style & $70 \%$ & $30 \%$ \\
\hline 3 & Improved of Clothing & $80 \%$ & $20 \%$ \\
\hline 4 & Improved of Qualitative food & $70 \%$ & $30 \%$ \\
\hline 5 & Improved of High thinking & $40 \%$ & $60 \%$ \\
\hline 6 & Improved of Way of approach & $50 \%$ & $50 \%$ \\
\hline 7 & Improved of Modernization & $60 \%$ & $40 \%$ \\
\hline 8 & Improved of Connectivity with cities & $90 \%$ & $10 \%$ \\
\hline 9 & Improved of Public rel ationships & $50 \%$ & $50 \%$ \\
\hline 10 & Improved of Political contacts & $80 \%$ & $20 \%$ \\
\hline 11 & Improved of Participation in politics & $85 \%$ & $15 \%$ \\
\hline 12 & Improved of Economy & $70 \%$ & $30 \%$ \\
\hline 13 & Improved of Assets & $80 \%$ & $20 \%$ \\
\hline 14 & Improved of Vehicles & $90 \%$ & $10 \%$ \\
\hline 15 & Improved of Good housing & $60 \%$ & $40 \%$ \\
\hline 16 & Improved in daily expenditures & $75 \%$ & $25 \%$ \\
\hline
\end{tabular}


1. Afterusing petroleum based machines the education level of grower's family improved because of their increase in income. By their income they moved for professional educational also.

2. By raise in income their life style also changed from normal to improved condition.

3. Due to availability of funds both male and female started wearing quality cloths as a mark of social development.

4. Due to availability more income growers started consuming qualitative and nourishing food.

5. Due to availability of funds in their hands they are not in a position to think globally and act locally. Thinking in the interest of society concept is slowly disappearing.

6. After earning more money from the crop their social way of approach is also changed to $50 \%$. Another $50 \%$ remains in the old way of social approach.

7. After using petroleum based machines growers improved a lot in modernization also.

8. After more earning the connectivity concept reached the peak. By the way of mobile phones, laptops, I phones and vehicles.

9. After using petroleum based machines their public relationship also improved the $50 \%$, another $50 \%$ remains as in usual way.

10. By more earnings grower's political contacts improved a lot.

11. By more earnings growers started more participation in local politics.

12. By using petroleum based machines their economy improved a lot by saving in labor cost.

13. By more income growers assets are also increased. Growers started buying others assets which is adjacent to their own lands.

14. By more income growers purchased more vehicles for their utility and cultivation.

15. Majority of the growers started constructing new homes with bank facilities and their housing activity also extended.

16. Due to availability of more funds in their hands majority of the growers spending more money. 
Role of petroleum Based Machines in Socio - Economic Development of Areca nut growers -A Sociological study

R.Devananda, Dr. G. D Narayana

\section{Table -4 Problems of Areca nut growers}

\begin{tabular}{|c|c|c|c|}
\hline S1. no & Problems of Areca nut growers & YES & No \\
\hline 1 & barrowed loans from banks to buy petrol eum based machines & $90 \%$ & $10 \%$ \\
\hline 2 & mentally worry to re-pay the loans & $90 \%$ & $10 \%$ \\
\hline 3 & Demand for the loan waver received from govt. and private hands. & $70 \%$ & $30 \%$ \\
\hline 4 & $\begin{array}{l}\text { feel very difficult to maintain the Aracanut garden from various } \\
\text { daises }\end{array}$ & $90 \%$ & $10 \%$ \\
\hline 5 & global warming is effecting the Aracanut crop & $95 \%$ & $5 \%$ \\
\hline 6 & the government should intervene in price fall of Aracanut & $100 \%$ & $0 \%$ \\
\hline 7 & supporting price should be declare the government & $95 \%$ & $5 \%$ \\
\hline 8 & Aracanut cultivation extension should be stopped & $10 \%$ & $90 \%$ \\
\hline 9 & Aracanut import should be banned & $95 \%$ & $5 \%$ \\
\hline 10 & $\begin{array}{l}\text { scientists should work more to find the medicines for diesis of } \\
\text { Aracanut }\end{array}$ & $99 \%$ & $1 \%$ \\
\hline 11 & govt. should bring a policy for Aracanut crop & $95 \%$ & $5 \%$ \\
\hline 12 & $\begin{array}{l}\text { govt. provide sufficient funds to research and development for } \\
\text { Aracanut }\end{array}$ & $99 \%$ & $1 \%$ \\
\hline 13 & $\begin{array}{l}\text { new Aracanut board is necessary to take care of Aracanut crop and } \\
\text { growers }\end{array}$ & $5 \%$ & $95 \%$ \\
\hline 14 & $\begin{array}{l}\text { directorate of Aracanut and spices development is sufficient to take } \\
\text { care of Aracanut crop and growers }\end{array}$ & $95 \%$ & $5 \%$ \\
\hline 15 & weather based crop insurance helps the Aracanut growers & $95 \%$ & $5 \%$ \\
\hline 16 & there is a prospect for Aracanut crop & $60 \%$ & $40 \%$ \\
\hline 17 & food crops growing area is decreasing by a Aracanut crop & $98 \%$ & $2 \%$ \\
\hline 18 & $\begin{array}{l}\text { Do you feel inconvenience at the time of Non availability of } \\
\text { petrol eum products }\end{array}$ & $98 \%$ & $2 \%$ \\
\hline 19 & Do you feel any problem at a time of bands and strikes & $97 \%$ & $3 \%$ \\
\hline 20 & Do you feel petroleum products are costly & $98 \%$ & $2 \%$ \\
\hline
\end{tabular}

1. Majority of the growers borrowed loans from banks to by petroleum based machines by pledging their gardens and lands.

2. Majority of growers worry mentally to repay loans because they have not made proper provisions in their budget to repay the loans. Only $10 \%$ of the growers won't worry mentally repay the loans.

3. Majority of the growers demand for loan waver which was received from govt. and private hands because of price fall of Aracanut.

4. Majority of the growers feel very difficult maintain their garden because of new disease like YLD, Root rat, mites and so on.

5. Majority of the growers feel global warming is damaging the Aracanut yield per hectare.

6. Majority of the growers demand govt. should intervene in the price fall of Aracanut. 
7. Majority of the growers demand for supporting price for Aracanut.

8. Only $10 \%$ of the growers opine that Aracanut cultivation extension should be stopped on the basis of exes' production of Aracanut crop and demand $\mathrm{v} /$ s supply formula. $90 \%$ of the growers blindly go for extension of Aracanut crop.

9. $95 \%$ of the growers opine that Aracanut import should be banned from the foreign countries. It will affect local growers badly. Only $5 \%$ of the growers support import of Aracanut according to 'dankle and gatt agreement'.

10. Majority of the growers feel the scientists should work more to find the solutions for farmer's problems regarding daisies.

11. Majority of the growers demand for a govt. national policy on Aracanut crop.

12. Majority of the growers demand for adequate funds for research and development of Aracanut.

13. Majority of the growers do not support formation of new Aracanut board.

14. Majority of the growers feel the existing directorate of Aracanut spice development is sufficient for welfare of Aracanut.

15. Majority of the grower's supports weather based crop insurance by NDA Govt.

16. Only $60 \%$ of the growers feel there is a prospect of for Aracanut.

17. Majority of growers feel food growing area is decreasing by the extension of Aracanut crop.

18. Majority of the growers feel uncomfortable at the time of non availability of petroleum products for their petroleum based machines and their work will suffer, their progress will also suffer.

19. Majority of growers feel uncomfortable at the time of bands and strikes because they are not able to buy the petroleum products for their petroleum based machines, which is entirely depending upon petroleum products only.

20. Majority of the growers feel petroleum products very costly and it is sometimes unaffordable for small and marginal farmers.

\section{Findings}

- The present situation of Aracanut growers after the commencement of using the petroleum based machines in Aracanut cultivation, they achieved a lot, they saved labor, they saved money, they saved time, and they have utilized natural resources in a very good manner with efficiency. 
Role of petroleum Based Machines in Socio - Economic Development of Areca nut growers -A Sociological study

R.Devananda, Dr. G. D Narayana

- By using petroleum based machines in Aracanut cultivation their economic condition improved a lot.

- By earning more money by utilizing petroleum based machines in Aracanut cultivation their social condition also improved in the society.

\section{Prove meant of Hypotheses}

ü By Above all studies and statics collected from responded indicates Aracanut growers economic condition is moving from normal condition to good condition. Simultaneously their social conditions in the society also improving and majority of Aracanut growers are fully depending upon petroleum based machines for their Aracanut cultivation and their lively hood.

\section{Suggestions}

By my studies I can suggest my Aracanut growers not to extend Aracanut crop from here after words. But the present Aracanut garden should be maintained in the interest of nation and Aracanut growers. The govt. should evolve a new govt. national policy on Aracanut crop.

\section{Conclusions}

The Aracanut growers who are using petroleum based machines for their Aracanut cultivation should be more conscious about their loan, which was raised for the development of Aracanut crop. Aracanut growers should think like economist regarding their investment and future profits. Aracanut growers should be calculative in monitory items. In the same time the Aracanut growers, growers' societies, marketing societies, NGO's and the govt. should think seriously about the existence of the crop because there is a legal battle in the apex court of India. Nobody knows about the future of Aracanut market. The govt. should monitor the import and export of Aracanut timely. The govt. should come out national policy regarding the Aracanut crop, because now Aracanut is a subject for debate in the eyes of market, in the eyes world health organization and others.

The govt. should work out the production cost of the Aracanut per quintal and a profitable margin should be added to the production cost, the total should be supporting price for the Aracanut. By the above means we can register a integrated growth of Aracanut growers socio-economically.

\section{References}

1. SingaraBangarastudy an Aracanut2014, bysharathkalkod. Publishers MAMCOS Shivmogga.

2. High court of Karnatakaproceedings. W P No:38220/2003 (GM-RES) 
3. Supreme court of India proceedings. SLP (Civil) 16308/2007. ANUKUR GUTAKA v/s INDIAN ASTHAMA CARE SOCIETY \& ORS.

4. Agriculture and Horticulture University Shivmogga, Aracanut Research Center Shivmogga.

5. KRUSHI BHARATH Monthly Magazines, Editor: Chandrashekar Bale.

6. VOLUME 31 CATEGORY OF FRUITS (III), DRUG 31-13 BINLANG Areca, Betel, Areca Catechu L.-Drug of medium classes in MingyiBielu. (Pharmaceutical studies) China.

7. News papers, Magazines, websites 